\title{
Ultrasound-assisted aqueous enzymatic extraction of oil from perilla seeds and determination of its physicochemical properties, fatty acid composition and antioxidant activity
}

\author{
Huizhen $\mathrm{LI}^{1}$, Zhijun ZHANG ${ }^{1 \star}$, Dongliang $\mathrm{HE}^{1}$, Yaoyao XIA ${ }^{1}$, Qingye LIU ${ }^{1}$, Xiaojun $\mathrm{LI}^{1}$
}

\begin{abstract}
Response surface methodology (RSM) was used to optimize ultrasound-assisted aqueous enzymatic extraction (UAAEE) conditions for perilla seed oil. Under the optimum conditions-which were a liquid-to-solid ratio of 4.4:1, a hydrolysis time of $2.66 \mathrm{~h}$, a hydrolysis temperature of $50.87^{\circ} \mathrm{C}$ and an ultrasound treatment time of $24.74 \mathrm{~min}$-an oil yield of $31.34 \%$ was obtained. Comparisons of the physicochemical characteristics of oil obtained using UAAEE with those of oil obtained by solvent extraction (SE oil) and cold pressing extraction (CPE oil) revealed similar refractive indices and saponification values, but UAAEE oil had a higher iodine value and better stability against oxidation, with a low peroxide value. UAAEE oil contained higher levels of beneficial $a$-linolenic acid and phenolics than SE oil or CPE oil, and it also had superior efficiency in scavenging 2,2-diphenyl-1-picrylhydrazyl (DPPH) radicals.
\end{abstract}

Keywords: perilla seed oil; ultrasound-assisted aqueous enzymatic extraction; physical and chemical characteristics; fatty acid composition; antioxidant activities.

Practical Application: Based on its physical and chemical properties, perilla oil obtained using UAAEE would be suitable as high quality edible oil and could also have applications in the cosmetic and pharmaceutical industries.

\section{Introduction}

Perilla (Perilla frutescens) is an annual herb that is widely used for cooking and medicinal purposes in several Asian countries (Igarashi \& Miyazaki, 2013), including China, Japan and Korea. Perilla seed oil is rich in omega-3 fatty acids (53.6\%-64\%), especially $\alpha$-linolenic acid (ALA, 18:3, n-3, $52.58 \%-61.98 \%$ ) (Zhou et al., 2014). ALA is metabolized to long-chain polyunsaturated fatty acids (LC-PUFA) such as eicosapentaenoic acid (EPA, 20:5, n-3) and docosahexaenoic acid (DHA, 22:6, n-3), which are especially important during human brain development (Lee \& Song, 2012). Because of its high omega-3 fatty acid content, perilla seed oil also has the potential to lower the risk of many chronic diseases. It may reduce inflammation, prevent abnormal clotting, relax blood vessels, and have anticancer properties (Asif, 2011; Li et al., 2014).

Perilla seed oil is typically obtained either by mechanical pressing or by extraction using organic solvents. However, the yield obtained by mechanical pressing is quite low and the use of organic solvents causes unacceptable contamination of the environment and residues in the oil may be harmful to human health (Zhang et al., 2010). Aqueous enzymatic extraction (AEE) has been successfully used for the extraction of oils from a variety of oil-bearing seeds, including olive (Najafian et al., 2009) and peanut (Jiang et al., 2010). Ultrasound has been shown to accelerate heat and mass transfer and is a powerful alternative to conventional extraction techniques. The strong mass transmission effect, which is mainly caused by cavitational effects (Chemat et al., 2011), could be used to enhance the extraction efficiency of AEE for edible oils. Ultrasound-assisted extraction (UAE) has many advantages, including high extraction yields, high reproducibility, low solvent use, short extraction times, low running costs, limited environment impact and easy adaptation to industrial scale use (Vuong et al., 2014).

In the present study, optimal conditions for ultrasound-assisted aqueous enzymatic extraction (UAAEE) of oil from perilla seeds were investigated using response surface methodology (RSM). The fatty acid composition, physicochemical properties and antioxidant activities of perilla seed oil extracted by UAAEE were evaluated and compared with those of mechanically pressed oil and oil extracted using organic solvent.

\section{Materials and methods}

\subsection{Plant materials and reagents}

P. frutescens seeds (oil content $37.8 \%$ ) were collected in October 2014 from the North University of China (Taiyuan, Shanxi Province, China). The dried seeds were milled to approximately $250 \mu \mathrm{m}$ and stored in airtight containers at $4{ }^{\circ} \mathrm{C}$ until use. Chemical reagents were supplied by Beijing Chemical Reagents Co. (Beijing, China). 


\subsection{Soxhlet extraction (SE) and cold pressing extraction (CPE)}

Perilla seeds (dried and milled, $5 \mathrm{~g}$ ) were extracted with $n$-hexane $(250 \mathrm{~mL})$ in a Soxhlet extractor at $90{ }^{\circ} \mathrm{C}$ for $7 \mathrm{~h}$. The $n$-hexane was removed at $50{ }^{\circ} \mathrm{C}$ under reduced pressure using a rotary evaporator (SHZ-95B, Yuhua Ltd., Gongyi, Henan, China). SE gave an extraction yield of $35.2 \%(w / w)$. An oil sample was also prepared by CPE. The oil samples were stored in glass vials at $4{ }^{\circ} \mathrm{C}$ prior to physical and chemical characterization.

\subsection{Ultrasound-assisted aqueous enzymatic extraction (UAAEE)}

Powdered perilla seeds (15 g) were pretreated with water (water/seed ratio, $3: 1$ to $7: 1 \mathrm{~mL} / \mathrm{g}$ ) in a tunable ultrasonic bath (TH-400BQG, 50Hz; Tianhua Ultrasonic Electronic Equipment Co., Ltd., Jining, Shandong, China) at $30^{\circ} \mathrm{C}$ for $20 \mathrm{~min}-30 \mathrm{~min}$ at a power of $400 \mathrm{~W}$. An enzyme cocktail (cellulase (5.5\%) / neutral proteinase $(4.5 \%)$ / pectinase $(7.5 \%)$ ) was then added and the mixture was incubated in a water bath at $45^{\circ} \mathrm{C}-55^{\circ} \mathrm{C}$ for $2 \mathrm{~h}-3 \mathrm{~h}$ with constant stirring. Before adding the enzymes, the $\mathrm{pH}$ of the mixture was adjusted to 7.0 using $0.5 \mathrm{M} \mathrm{NaOH}$ and $0.5 \mathrm{M} \mathrm{HCl}$. After the extraction process, the mixture was centrifuged at $8000 \mathrm{~g}$ for $20 \mathrm{~min}$ at room temperature, giving three layers (oil, cream and skim). The uppermost oil layer was carefully removed using a micropipette. The oil yield per seed sample (100 g), on a dry-weight basis, was determined using the Equation 1:

Oil yield $(\%)=($ weight of extracted oil / weight of seeds $) \times 100 \%$

\subsection{RSM design and statistical analysis}

Based on the results of a preliminary mono-factor test (data not shown), a Box-Behnken design (BBD) was used to determine the effects of four independent variables, i.e., liquid/solid ratio $\left(X_{1}\right)$, hydrolysis time $\left(X_{2}\right)$, hydrolysis temperature $\left(X_{3}\right)$ and ultrasound treatment time $\left(X_{4}\right)$, on perilla oil yield $(Y)$. The independent variables were coded at three levels $(-1,0$, and 1$)$. The complete design consisted of 29 experimental points, including five replicates of the central points (all variables were coded as zero). A randomized experimental order was used to reduce the effect of unexplained variability on the observed responses. The run order, variable conditions, and experimental and predicted values are shown in Table 1. A regression analysis was carried

Table 1. Box-Behnken design and observed responses of perilla oil yield using UAAEE.

\begin{tabular}{|c|c|c|c|c|c|c|}
\hline \multirow{2}{*}{ Run } & \multirow{2}{*}{$\begin{array}{l}\text { Liquid-solid ratio } \\
\qquad \mathrm{X}_{1}(\mathrm{~mL}: \mathrm{g})\end{array}$} & \multirow{2}{*}{$\begin{array}{l}\text { Hydrolysis ttime } \\
\mathrm{X}_{2}(\mathrm{~h})\end{array}$} & \multirow{2}{*}{$\begin{array}{c}\text { Hydrolysis } \\
\text { temperature } \\
\mathrm{X}_{3}\left({ }^{\circ} \mathrm{C}\right)\end{array}$} & \multirow{2}{*}{$\begin{array}{l}\text { Ultrasonic } \\
\text { time } \\
\mathrm{X}_{4}(\mathrm{~min})\end{array}$} & \multicolumn{2}{|c|}{ Oil yield (\%) } \\
\hline & & & & & $\begin{array}{c}\text { Experimental } \\
\text { values }\end{array}$ & predicted values \\
\hline 1 & $5: 1$ & 2.0 & 50 & 30 & 27.53 & 26.67 \\
\hline 2 & $5: 1$ & 2.5 & 55 & 30 & 28.33 & 28.42 \\
\hline 3 & $7: 1$ & 2.5 & 50 & 20 & 25.13 & 25.32 \\
\hline 4 & $7: 1$ & 2.0 & 50 & 25 & 24.67 & 24.48 \\
\hline 5 & $7: 1$ & 2.5 & 45 & 25 & 25.67 & 25.74 \\
\hline 6 & $5: 1$ & 3.0 & 45 & 25 & 28.53 & 28.03 \\
\hline 7 & $5: 1$ & 3.0 & 50 & 30 & 27.93 & 27.28 \\
\hline 8 & $5: 1$ & 2.0 & 55 & 25 & 26.07 & 26.36 \\
\hline 9 & $5: 1$ & 3.0 & 50 & 20 & 28.13 & 28.75 \\
\hline 10 & $3: 1$ & 2.5 & 45 & 25 & 28.47 & 28.42 \\
\hline 11 & $5: 1$ & 2.5 & 50 & 25 & 31.33 & 30.96 \\
\hline 12 & $5: 1$ & 2.5 & 50 & 25 & 31.27 & 30.96 \\
\hline 13 & $5: 1$ & 2.5 & 50 & 25 & 29.33 & 30.96 \\
\hline 14 & $5: 1$ & 2.5 & 50 & 25 & 31.40 & 30.96 \\
\hline 15 & $5: 1$ & 2.5 & 45 & 20 & 27.73 & 28.09 \\
\hline 16 & $5: 1$ & 2.0 & 45 & 25 & 27.93 & 27.09 \\
\hline 17 & $3: 1$ & 2.0 & 50 & 25 & 24.47 & 25.66 \\
\hline 18 & $7: 1$ & 2.5 & 50 & 30 & 24.13 & 24.99 \\
\hline 19 & $5: 1$ & 3.0 & 55 & 25 & 28.87 & 29.50 \\
\hline 20 & $5: 1$ & 2.5 & 45 & 30 & 26.93 & 27.89 \\
\hline 21 & $5: 1$ & 2.5 & 55 & 20 & 28.80 & 28.29 \\
\hline 22 & $3: 1$ & 3.0 & 50 & 25 & 28.60 & 29.23 \\
\hline 23 & $3: 1$ & 2.5 & 50 & 30 & 28.40 & 28.00 \\
\hline 24 & $7: 1$ & 3.0 & 50 & 25 & 25.73 & 24.99 \\
\hline 25 & $5: 1$ & 2.5 & 50 & 25 & 31.47 & 30.96 \\
\hline 26 & $7: 1$ & 2.5 & 55 & 25 & 26.27 & 26.08 \\
\hline 27 & $3: 1$ & 2.5 & 55 & 25 & 29.13 & 28.82 \\
\hline 28 & $5: 1$ & 2.0 & 50 & 20 & 24.87 & 25.28 \\
\hline 29 & $3: 1$ & 2.5 & 50 & 20 & 28.80 & 27.74 \\
\hline
\end{tabular}


out to evaluate the response function as a quadratic polynomial (Equation 2):

$$
Y=\beta_{0}+\sum_{i=1}^{4} \beta_{i} X_{i}+\sum_{i=1}^{4} \beta_{i i} X_{i}^{2}+\sum_{i=1}^{3} \sum_{j=i+1}^{4} \beta_{i j} X_{i} X_{j}
$$

where $\mathrm{Y}$ is the response variable (oil yield); $\beta_{0}$ is the offset term, $\beta_{\mathrm{i}}$ is the linear effect, $\beta_{\mathrm{ii}}$ is the squared effect, $\beta_{\mathrm{ij}}$ is the interaction effect and $X_{\mathrm{i}}$ and $X_{\mathrm{j}}$ are independent variables.

Data were analyzed by one-way analysis of variance (ANOVA) to determine the lack of fit and the effects of linear, quadratic, and interaction variables on perilla oil extraction yields. Data analyses and RSM were performed using Design-Expert ${ }^{\circledR}$ Software version 8 (Stat-Ease, Inc., Minneapolis, MN, USA).

\subsection{Characterization of perilla oil}

Refractive indices were determined using a Series RA-130 refractometer (KEM-China, Shanghai, China). ISO (International Organization for Standardization) standard methods were used for the determination of peroxide value, acid value, iodine value, saponification value, and unsaponifiable matter.

\subsection{Fatty acid composition}

The fatty acid composition of the perilla seed oils was analyzed using an HP-7900 gas chromatograph (Tianmei Scientific Instrument Co., Ltd., Shanghai, China), according to the method of Li et al. (2015).

\subsection{Determination of total tocopherols (TT) and total phenolics (TP)}

The TT contents of perilla seed oils were determined using the colorimetric method described by Wong et al. (1988). The TP contents were determined using the Folin-Ciocalteu method (Capannesi et al., 2000).

\subsection{DPPH scavenging activity}

The DPPH radical-scavenging activity of perilla seed oil extracted using UAAEE was determined using the method described by Long et al. (2011).

\section{Results and discussion}

\subsection{Fitting the mathematical model}

The ANOVA results for the quadratic model are shown in Table 2 . The model $F$ value $(9.14)$ and low $P$ value $(P<0.0001)$ showed that the model was statistically significant. A model is considered to be adequate when the coefficient of determination $\left(R^{2}\right)$ is $>0.75$. In this case, $R^{2}=0.9014$ (indicating that $90.14 \%$ of the experimental oil yield values matched the model-predicted values) and is sufficient to validate the significance of the model. Furthermore, lack of fit, which measures the fitness of the model, was not significant $(P>0.05)$. Based on these factors, the mathematical model was considered to be adequate for the prediction of oil yield and was fitted to the following second-order polynomial equation, $\mathrm{Y}=30.960-1.356 \mathrm{X}_{1}+1.021 \mathrm{X}_{2}+0.184 \mathrm{X}_{3}$ $-0.018 \mathrm{X}_{4}-0.768 \mathrm{X}_{1} \mathrm{X}_{2}-0.015 \mathrm{X}_{1} \mathrm{X}_{3}-0.150 \mathrm{X}_{1} \mathrm{X}_{4}+0.550 \mathrm{X}_{2} \mathrm{X}_{3}-$ $0.715 \mathrm{X}_{2} \mathrm{X}_{4}+0.083 \mathrm{X}_{3} \mathrm{X}_{4}-2.676 \mathrm{X}_{1}^{2}-2.194 \mathrm{X}_{2}^{2}-1.019 \mathrm{X}_{3}^{2}-1.771 \mathrm{X}_{4}^{2}$.

Table 2. Analysis of variance (ANOVA) for the quadratic polynomial mode.

\begin{tabular}{|c|c|c|c|c|c|}
\hline source & Sum of squares & $\mathrm{df}$ & Mean square & $F$ value & $\begin{array}{c}P \text {-value } \\
\text { Prob } F\end{array}$ \\
\hline Model & 113.25 & 14 & 8.09 & 9.14 & $<0.0001$ \\
\hline $\mathrm{X}_{1}$ & 22.06 & 1 & 22.06 & 24.92 & 0.0002 \\
\hline $\mathrm{X}_{2}$ & 12.51 & 1 & 12.51 & 14.13 & 0.0021 \\
\hline $\mathrm{X}_{3}$ & 0.41 & 1 & 0.41 & 0.46 & 0.5088 \\
\hline $\mathrm{X}_{4}$ & 0.004 & 1 & 0.004 & 0.004 & 0.9495 \\
\hline $\mathrm{X}_{1} \mathrm{X}_{2}$ & 2.36 & 1 & 2.36 & 2.66 & 0.1251 \\
\hline $\mathrm{X}_{1} \mathrm{X}_{3}$ & 0.0009 & 1 & 0.0009 & 0.001 & 0.9750 \\
\hline $\mathrm{X}_{1} \mathrm{X}_{4}$ & 0.09 & 1 & 0.09 & 0.10 & 0.7546 \\
\hline $\mathrm{X}_{2} \mathrm{X}_{3}$ & 1.21 & 1 & 1.21 & 1.37 & 0.2619 \\
\hline $\mathrm{X}_{2} \mathrm{X}_{4}$ & 2.04 & 1 & 2.04 & 2.31 & 0.1508 \\
\hline $\mathrm{X}_{3} \mathrm{X}_{4}$ & 0.03 & 1 & 0.03 & 0.03 & 0.8633 \\
\hline $\mathrm{X}_{1}^{2}$ & 46.46 & 1 & 46.46 & 52.48 & $<0.0001$ \\
\hline $\mathrm{X}_{2}^{2}$ & 31.22 & 1 & 31.22 & 35.26 & $<0.0001$ \\
\hline $\mathrm{X}_{3}^{2}$ & 6.73 & 1 & 6.73 & 7.60 & 0.0154 \\
\hline $\mathrm{X}_{4}^{2}$ & 20.35 & 1 & 20.35 & 22.99 & 0.0003 \\
\hline Residual & 12.39 & 14 & 0.89 & & \\
\hline Lack of fit & 9.05 & 10 & 0.91 & 1.08 & 0.5123 \\
\hline Pure error & 3.34 & 4 & 0.84 & & \\
\hline Cor total & 125.65 & 28 & & & \\
\hline $\mathrm{R}^{2}$ & 0.9014 & & & & \\
\hline Adj. $R^{2}$ & 0.8027 & & & & \\
\hline
\end{tabular}

${ }^{\text {a }} P<0.01$ highly significant; $0.01<P<0.05$ significant; $P>0.05$ not significant. 
The effects of $\mathrm{X}_{1}, \mathrm{X}_{2}, \mathrm{X}_{1}^{2}, \mathrm{X}_{2}^{2}$ and $\mathrm{X}_{4}^{2}$ on oil yield were highly significant $(P<0.01)$. Similarly, the effect of $\mathrm{X}_{3}{ }^{2}$ was significant $(P<0.05)$. On the other hand, $\mathrm{X}_{3}, \mathrm{X}_{4}, \mathrm{X}_{1} \mathrm{X}_{2}, \mathrm{X}_{1} \mathrm{X}_{3}, \mathrm{X}_{1} \mathrm{X}_{4}, \mathrm{X}_{2} \mathrm{X}_{3}$, $\mathrm{X}_{2} \mathrm{X}_{4}$ and $\mathrm{X}_{3} \mathrm{X}_{4}$ had no significant effects $(P>0.05)$ on oil yield. Based on the linear and quadratic coefficients, we concluded that the order of importance of different variables on oil yield was: liquid-to-solid ratio $>$ hydrolysis time $>$ hydrolysis temperature $>$ ultrasound treatment time.
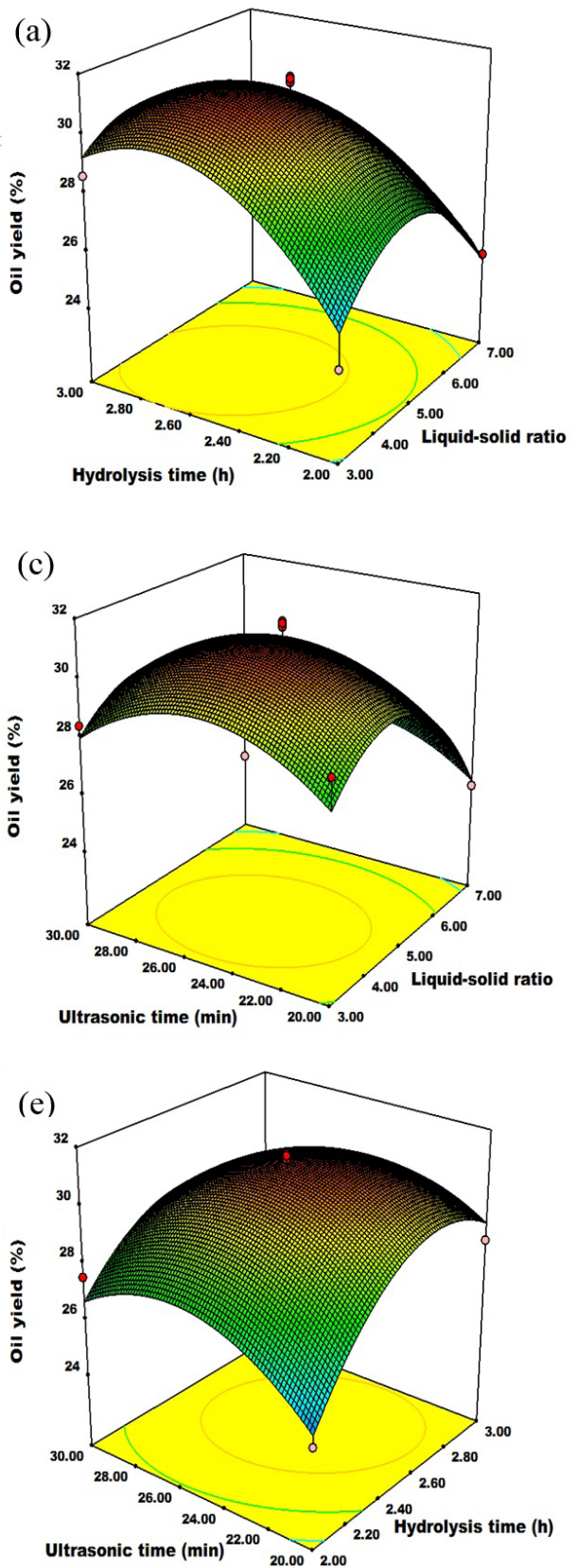

\subsection{RSM analysis}

The best way to visualize the effect of independent variables on a dependent variable is to draw three-dimensional (3D) response surface curves of the model. The 3D plot of the response surface for the oil yield against the liquid-to-solid ratio and hydrolysis time shows that a moderate liquid-to-solid ratio resulted in a high extraction yield (Figure 1a). As the hydrolysis time increased, the oil yield increased until it reached a plateau at $>2.66 \mathrm{~h}$ and subsequently decreased slightly.
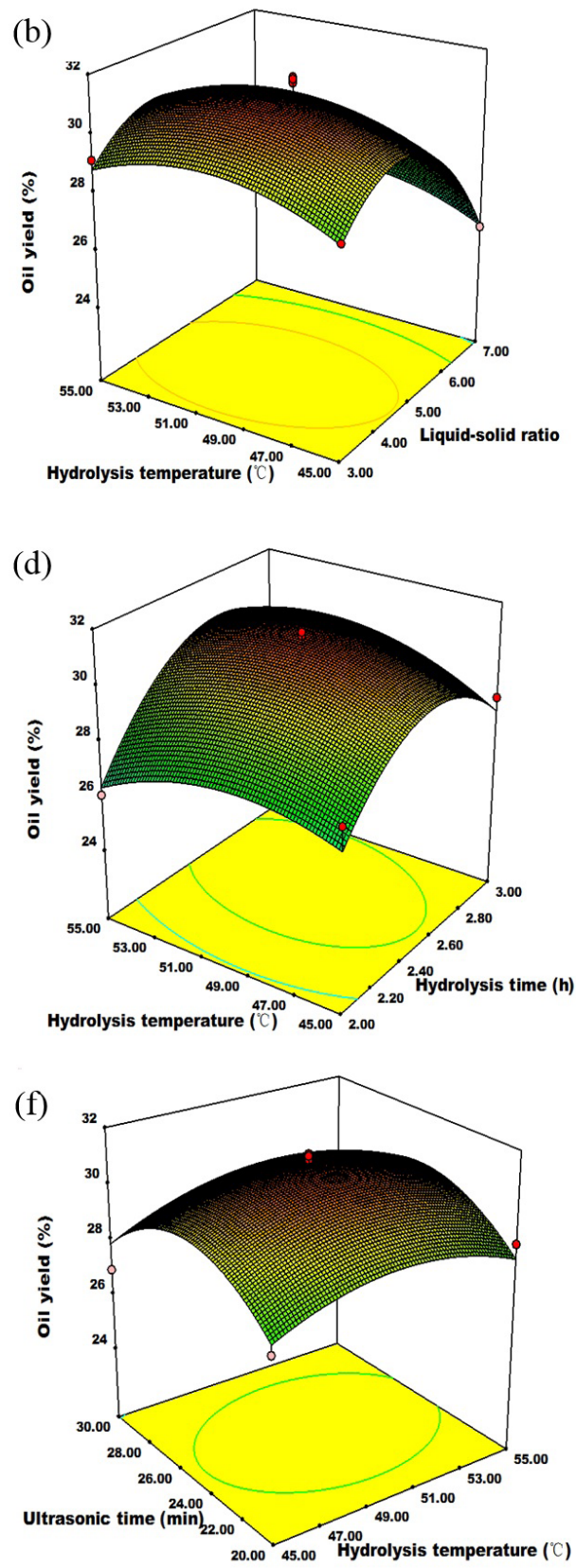

Figure 1. Response surface plots showing correlation of (a) liquid-solid ratio and hydrolysis time; (b) liquid-solid ratio and hydrolysis temperature; (c) liquid-solid ratio and ultrasonic time; (d) hydrolysis time and hydrolysis temperature; (e) hydrolysis time and ultrasonic time, and (f) hydrolysis temperature and ultrasonic time on the oil yield obtained using Ultrasound-assisted aqueous enzymatic extraction (UAAEE). 
A medium liquid-to-solid ratio and long hydrolysis time were favorable for extracting perilla oil (Figure $1 \mathrm{~b}$ and Figure 1d). The influence of the independent variable, hydrolysis temperature, was not as significant as those of the liquid-to-solid ratio and hydrolysis time. The oil yield increased with increasing temperature up to $50.87^{\circ} \mathrm{C}$. Similar effects on the extraction yield were seen in the curves for liquid-to-solid ratio and ultrasound treatment time (Figure 1c), and hydrolysis time and ultrasound treatment time (Figure 1e).

The best oil yields were obtained with hydrolysis temperatures of $50.87{ }^{\circ} \mathrm{C}$ and ultrasound treatment times of $24.74 \mathrm{~min}$ (Figure 1f). It is likely that increases in hydrolysis temperature and ultrasound treatment time shorten the time of mass transfer and improve oil extraction rates.

\subsection{Verification of the predictive model}

According to the second-order polynomial equation, the optimum conditions for oil yield were: liquid-to-solid ratio, 4.4:1; hydrolysis time, $2.66 \mathrm{~h}$; hydrolysis temperature, $50.87^{\circ} \mathrm{C}$; and ultrasound treatment time, $24.74 \mathrm{~min}$. Under these conditions, the predicted oil yield was $31.34 \%$, which was lower than that obtained by SE (35.2\%) but higher than that obtained by CPE (28.6\%). To further validate the reliability of the theoretical model prediction, verification experiments $(n=3)$ were carried out under optimal conditions. The experimental value (31.28\%) was found to be consistent with the predicted value. Therefore, the oil extraction conditions obtained using RSM were not only accurate and reliable, but also had practical value (Xu et al., 2013).

\subsection{Physicochemical characteristics and fatty acid composition of perilla oil}

The physicochemical characteristics of the perilla oils obtained by UAAEE, SE and CPE are shown in Table 3. At room temperature, all oil samples were yellow and there were no significant differences $(p>0.05)$ in their refractive indices $(1.479-1.481)$. The iodine values of UAAEE oil ( $210.654 \mathrm{~g} / 100 \mathrm{~g}$ oil $)$ and SE oil $(213.192 \mathrm{~g} / 100 \mathrm{~g}$ oil $)$ were significantly higher $(p<0.05)$ than that of CPE oil (196.695 g/100 g oil), which suggests that UAAEE oil and SE oil have higher levels of unsaturated fatty acids (Table 3 ). However, the acid value of UAAEE oil $(3.058 \mathrm{mg} / \mathrm{g}$ oil) was significantly higher $(p<0.05)$ than that of SE oil $(1.299 \mathrm{mg} / \mathrm{g}$ oil $)$ or CPE oil (1.143 mg/g oil). This difference may be caused by the action of endogenous lipases, which were not immediately inactivated during the extraction process. The peroxide value of UAAEE oil (3.2 meq. $\mathrm{O}_{2} / \mathrm{kg}$ oil) was also significantly lower $(p<0.05)$ than that of $\mathrm{CPE}$ oil $\left(4.3\right.$ meq. $\mathrm{O}_{2} / \mathrm{kg}$ oil $)$ or SE oil (4.5 meq. $\mathrm{O}_{2} / \mathrm{kg}$ oil). The higher peroxide value of $\mathrm{SE}$ oil is probably attributable to accelerated oxidation brought about by the elevated operational temperature and prolonged extraction time used in the conventional SE process (Latif \& Anwar, 2011). The saponification values (196.48 - $198.26 \mathrm{mg} \mathrm{KOH} / \mathrm{g}$ oil) of UAAEE oil, SE oil and CPE oil were not significantly different $(p>0.05)$. The values were, however, higher than those of other vegetable oils (Cerchiara et al., 2010; Li et al., 2015), indicating very high levels of low molecular weight triacylglycerols, which means that perilla oil is very suitable for the production of liquid soaps and shampoos.

The fatty acid composition of perilla oil is also shown in Table 3. Palmitic acid $\left(\mathrm{C}_{16: 0}, 4.43 \%-5.62 \%\right)$ and stearic acid $\left(\mathrm{C}_{18: 0}, 1.86 \%-1.92 \%\right)$ were the principal saturated fatty acids

Table 3. Physicochemical characteristics and fatty acid composition of perilla oil.

\begin{tabular}{lccc}
\hline & UAAEEO & SEO & CPEO \\
\hline Physicochemical characteristics & & & $1.479 \pm 0.001 \mathrm{a}$ \\
Refractive index & $1.480 \pm 0.001 \mathrm{a}$ & $1.481 \pm 0.002 \mathrm{a}$ & $1.143 \pm 0.02 \mathrm{c}$ \\
Acid value $(\mathrm{mg} / \mathrm{g}$ oil) & $3.058 \pm 0.03 \mathrm{a}$ & $1.299 \pm 0.03 \mathrm{~b}$ & $196.695 \pm 0.14 \mathrm{~b}$ \\
Iodine value $(\mathrm{g} / 100 \mathrm{~g}$ oil) & $210.654 \pm 0.35 \mathrm{a}$ & $213.192 \pm 0.50 \mathrm{a}$ & $197.82 \pm 0.45 \mathrm{a}$ \\
Saponification value $(\mathrm{mg}$ KOH/g oil) & $196.48 \pm 0.47 \mathrm{a}$ & $198.26 \pm 0.35 \mathrm{a}$ & $4.3 \pm 0.03 \mathrm{a}$ \\
Peroxide value (meq. $\mathrm{O}_{2} / \mathrm{kg}$ oil) & $3.2 \pm 0.03 \mathrm{~b}$ & $4.5 \pm 0.05 \mathrm{a}$ & $383.25 \pm 1.25 \mathrm{c}$ \\
Total tocopherol (mg/kg) & $450.88 \pm 1.35 \mathrm{~b}$ & $490.10 \pm 1.20 \mathrm{a}$ & $343.12 \pm 0.30 \mathrm{c}$ \\
Total phenolics $(\mathrm{mg}$ GAE/kg) & $615.25 \pm 0.66 \mathrm{a}$ & $410.50 \pm 0.45 \mathrm{~b}$ & Liquid \\
Physical state at room temperature & Liquid & Liquid & \\
Fatty acid composition $(\%)$ & & & $5.62 \pm 0.01 \mathrm{a}$ \\
Palmitic acid $\left(\mathrm{C}_{16: 0}\right)$ & $4.43 \pm 0.05 \mathrm{c}$ & $4.70 \pm 0.02 \mathrm{~b}$ & $1.92 \pm 0.02 \mathrm{a}$ \\
Stearic acid $\left(\mathrm{C}_{18: 0}\right)$ & $1.87 \pm 0.01 \mathrm{a}$ & $1.86 \pm 0.01 \mathrm{a}$ & $21.16 \pm 0.10 \mathrm{a}$ \\
Oleic acid $\left(\mathrm{C}_{18: 1}\right)$ & $16.92 \pm 0.20 \mathrm{c}$ & $11.19 \pm 0.05 \mathrm{~b}$ \\
Linoleic acid $\left(\mathrm{C}_{18: 2}\right)$ & $14.53 \pm 0.15 \mathrm{a}$ & $60.11 \pm 0.15 \mathrm{c}$ \\
Linolenic acid $\left(\mathrm{C}_{18: 3}\right)$ & $62.26 \pm 0.35 \mathrm{~b}$ & $7.54 \mathrm{a}$ \\
SAFA & $9.12 \pm 0.08 \mathrm{c}$ & $6.56 \mathrm{~b}$ & $21.16 \mathrm{a}$ \\
MUFA & $64.05 \pm 0.20 \mathrm{a}$ & $16.92 \mathrm{c}$ & $71.3 \mathrm{c}$ \\
PUFA & $6.30 \mathrm{c}$ & $76.79 \mathrm{a}$ & $92.46 \mathrm{~b}$ \\
TUFA & $20.39 \mathrm{~b}$ & $93.71 \mathrm{a}$ & $9.46 \mathrm{~b}$ \\
P/S & $73.17 \mathrm{~b}$ & $11.71 \mathrm{a}$ &
\end{tabular}

Mean values \pm standard deviation $(\mathrm{n}=3$ ) followed by different letters differ at $p<0.05$, according to Duncan (SSR) test. SAFA: Saturated fatty acids; MUFA: monounsaturated fatty acids; PUFA: polyunsaturated fatty acids; TUFA: total unsaturated fatty acids. 
(SFA); oleic acid $\left(\mathrm{C}_{18: 1}, 16.92 \%-21.16 \%\right)$ was the predominant monounsaturated fatty acid (MUFA); and linoleic acid $\left(\mathrm{C}_{18: 2}, 9.12 \%-13.53 \%\right)$ and ALA $\left(\mathrm{C}_{18: 3}, 60.11 \%-64.05 \%\right)$ were the two main polyunsaturated fatty acids (PUFA). Perilla seed oil is very rich in MUFA and PUFA, which account for $>90 \%$ of the total fatty acids, and contains relatively low amounts of SFA. Unsaturated fatty acids can affect the physical properties of cell membranes, including fluidity and permeability (Nasri et al., 2005). The omega-3 fatty acid ALA is a precursor of EPA and DHA, which are especially beneficial to human health (Lee \& Song, 2012). We have shown that the ALA content of UAAEE oil $(64.05 \%)$ is significantly higher $(p<0.05)$ than that of SE oil (62.26\%) or CPE oil (60.11\%). The oleic acid content of UAAEE oil $(20.39 \%)$ is also significantly higher $(p<0.05)$ than that of SE oil (16.92\%). Oleic acid is very important in the construction of nerve cells and has a fundamental role in the prevention of cardiovascular diseases (Nasri et al., 2005). The health benefits of perilla seed oil obtained by UAAEE were thus greater than those of oil obtained by conventional SE or CPE.

Perilla seed oil has a polyunsaturated/saturated $(\mathrm{P} / \mathrm{S})$ ratio in the range 9.46-11.71, which is demonstrated by its high refractive index. The $\mathrm{P} / \mathrm{S}$ ratio of UAAEE oil (11.61) is not significantly different $(p>0.05)$ from that of SE oil (11.71), but is significantly higher $(p<0.05)$ than that of CPE oil (9.46). A high $\mathrm{P} / \mathrm{S}$ ratio is associated with reduction of serum cholesterol levels and atherosclerosis risk and with the prevention of heart disease (Oomah et al., 2002).

\subsection{TT and TP content}

Tocopherols and phenolics are important antioxidants found in plant oils that act as chain-breakers in free radical chain reactions and convert lipid radicals into more stable products (Gai et al., 2013). We found that the TT content of SE oil $(490.10 \mathrm{mg} / \mathrm{kg})$ was significantly higher $(p<0.05)$ than that of UAAEE oil $(450.88 \mathrm{mg} / \mathrm{kg})$ or CPE oil $(383.25 \mathrm{mg} / \mathrm{kg})$. High amounts of tocopherols are typically associated with high PUFA content (Tuberoso et al., 2007) and we found a significant positive correlation between PUFA and TT content $(r=0.944)$. TP content in UAAEE oil $(615.25 \mathrm{mg} \mathrm{GAE} / \mathrm{kg})$ was, however, significantly higher $(p<0.05)$ than in SE oil $(410.50 \mathrm{mg}$ GAE/kg) or CPE oil (343.12 mg GAE/kg). TP content in UAAEE oil may be higher because enzymatic hydrolysis reduces the complexation of phenolic compounds with seed polysaccharides, proteins and pectins, thereby enhancing their partitioning into the oil phase (Ranalli et al., 2005). It is also noteworthy that TT content in perilla oil is higher $(383.88-490.10 \mathrm{mg} / \mathrm{kg})$ than in peanut oil $(165.5 \mathrm{mg} / \mathrm{kg})$ or rapeseed oil $(151.5 \mathrm{mg} / \mathrm{kg})$. TP content in perilla oil (343.12-615.25 mg GAE/ $\mathrm{kg}$ ) is higher than that in Albizia julibrissin oil (35.43 $\mathrm{mg} \mathrm{GAE} / \mathrm{kg}$ ), soybean oil (173.67 mg GAE/kg) or sesame seed oil (24.00 mg GAE/kg) (Nehdi, 2011; Latif \& Anwar, 2011). Perilla oil is thus a good source of the natural antioxidants, tocopherols and phenolics.

\subsection{Antioxidant activities}

As well as protecting the human body from diseases such as cancer, inflammation, rheumatoid arthritis and cardiovascular disorders (Tang et al., 2014), antioxidants are also able to prevent

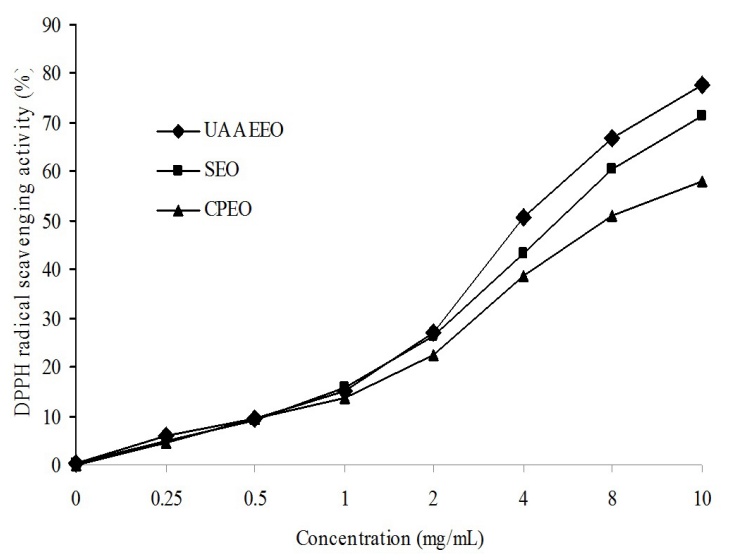

Figure 2. Antioxidant activities of the oils assessed by DPPH radicalscavenging assay.

food spoilage. Recently, interest in the antioxidant properties of plant seed oils and their benefits to human health has increased considerably.

DPPH radical-scavenging assays can be used as rapid and reliable tests for predicting the oxidative stability of fatty food such as oils, margarines and meat products (Gai et al., 2013). $\mathrm{DPPH}$ radical-scavenging activity was shown to increase with increasing concentration of perilla seed oils (Figure 2) UAAEE oil had a significantly $(p<0.05)$ lower $\mathrm{IC}_{50}$ value $(3.99 \mathrm{mg} / \mathrm{mL})$ than SE oil $(4.80 \mathrm{mg} / \mathrm{mL})$ or CPE oil $(7.19 \mathrm{mg} / \mathrm{mL})$, indicating that UAAEE oil has the best DPPH radical-scavenging activity. Previous studies have demonstrated that the antioxidant potential of plant oils can be attributed mainly to PUFA, tocopherols and phenolics (Gai et al., 2013). In the present study, UAAEE oil showed higher antioxidant activity than SE oil or CPE oil, likely because of the higher phenolic content of UAAEE oil (615.25 mg GAE/kg) compared with SE oil (410.50 mg GAE/kg) or CPE oil (343.12 mg GAE/kg). A significant $(p<0.05)$ negative correlation was seen between TP content and $\mathrm{IC}_{50}$ values $(r=-0.846)$.

\section{Conclusion}

In this study, a UAAEE method for perilla seed oil was optimized using RSM and an efficient, high performance, process was achieved. The optimum UAAEE conditions for perilla oil were: enzyme cocktail, cellulase (5.5\%) / neutral proteinase (4.5\%) / pectinase (7.5\%); liquid-to-solid ratio, 4.4:1; hydrolysis time, $2.66 \mathrm{~h}$; hydrolysis temperature, $50.87^{\circ} \mathrm{C}$; and ultrasound treatment time, $24.74 \mathrm{~min}$. Under these conditions, the predicted maximum oil yield was $31.34 \%$, which was lower than that obtained using SE (35.2\%) and higher than that obtained using CPE (28.6\%). The predicted oil yield value agreed well with the experimental value. Comparisons of the physicochemical characteristics of UAAEE oil with those of SE oil and CPE oil revealed similar refractive indices and saponification values, but UAAEE oil had a higher iodine value and better stability against oxidation, with a low peroxide value. Additionally, UAAEE oil contained high levels of beneficial ALA, which were significantly $(p<0.05)$ higher than those of SE oil or CPE 
oil. UAAEE oil was also more effective in scavenging DPPH radicals. The lower $\mathrm{IC}_{50}$ value compared with those of SE oil and CPE oil could be partly explained by the higher levels of phenolics in UAAEE oil (615.25 mg GAE/kg) compared with SE oil (410.50 mg GAE/kg) and CPE oil (343.12 mg GAE/kg). Overall, UAAEE is a promising and environmentally-friendly technique for oil extraction in the food industry. The present investigations indicate that perilla oil obtained using UAAEE is suitable for use as high quality edible oil and could also have applications in the cosmetic and food industries.

\section{Acknowledgements}

This work was supported by the Science and Technology Research Program of Shanxi Province in China (201503110094; 201603D321031).

\section{References}

Asif, M. (2011). Health effects of omega-3,6,9 fatty acid: Perilla frutescens is a good example of plant oils. Oriental Pharmacy and Experimental Medicine, 11(1), 51-59. PMid:21909287. http://dx.doi.org/10.1007/ s13596-011-0002-X.

Capannesi, C., Palchetti, I., Mascini, M., \& Parenti, A. (2000). Electrochemical sensor and biosensor for polyphenols detection in olive oils. Food Chemistry, 71(4), 553-562. http://dx.doi.org/10.1016/ S0308-8146(00)00211-9.

Cerchiara, T., Chidichimo, G., Ragusa, M. I., Belsito, E. L., Liguori, A., \& Arioli, A. (2010). Characterization and utilisation of Spanish Broom (Spartium junceum L.) seed oil. Industrial Crops and Products, 31(2), 423-426. http://dx.doi.org/10.1016/j.indcrop.2009.11.003.

Chemat, F., Zill-e-Huma, \& Khan, M. K. (2011). Applications of ultrasound in food technology: processing, preservation and extraction. Ultrasonics Sonochemistry, 18(4), 813-835. PMid:21216174. http:// dx.doi.org/10.1016/j.ultsonch.2010.11.023.

Gai, Q. Y., Jiao, J., Wei, F. Y., Luo, M., Wang, W., Zu, Y. G., \& Fu, Y. J. (2013). Enzyme-assisted aqueous extraction of oil from Forsythia suspense seed and its physicochemical property and antioxidant activity. Industrial Crops and Products, 51, 274-278. http://dx.doi. org/10.1016/j.indcrop.2013.09.014.

Igarashi, M., \& Miyazaki, Y. (2013). A review on bioactivities of perilla: progress in research on the functions of perilla as medicine and food. Evidence-Based Complementary and Alternative Medicine, 2013, 925342. PMid:24319488. http://dx.doi.org/10.1155/2013/925342.

Jiang, L., Hua, D., Wang, Z., \& Xu, S. (2010). Aqueous enzymatic extraction of peanut oil and protein hydrolysates. Food and Bioproducts Processing, 88(2-3), 233-238. http://dx.doi.org/10.1016/j. fbp.2009.08.002.

Latif, S., \& Anwar, F. (2011). Aqueous enzymatic sesame oil and protein extraction. Food Chemistry, 125(2), 679-684. http://dx.doi. org/10.1016/j.foodchem.2010.09.064.

Lee, J., \& Song, Y. O. (2012). Perilla oil rich in -linolenic acid suppresses hepatic SREBPs and NF- $\mathrm{KB}$ expression in hypercholesterolemia-induced apolipoprotein E knockout mice. Food Science and Biotechnology, 21(3), 807-813. http://dx.doi.org/10.1007/s10068-012-0104-3.

Li, H. Z., Zhang, Z. J., Hou, T. Y., Li, X. J., \& Chen, T. (2015). Optimization of ultrasound-assisted hexane extraction of perilla oil using response surface methodology. Industrial Crops and Products, 76, 18-24. http://dx.doi.org/10.1016/j.indcrop.2015.06.021.
Li, Y., Zhang, Y., Sui, X. N., Zhang, Y. N., Feng, H. X., \& Jiang, L. Z. (2014). Ultrasound-assisted aqueous enzymatic extraction of oil from perilla (Perilla frutescens L.) seeds. CYTA: Journal of Food, 12(1), 16-21. http://dx.doi.org/10.1080/19476337.2013.782070.

Long, J. J., Fu, Y. J., Zu, Y. G., Li, J., Wang, W., Gu, C. B., \& Luo, M. (2011). Ultrasound-assisted extraction of flaxseed oil using immobilized enzymes. Bioresource Technology, 102(21), 9991-9996. PMid:21890349. http://dx.doi.org/10.1016/j.biortech.2011.07.104.

Najafian, L., Ghodsvali, A., Khodaparast, M. H. H., \& Diosady, L. L. (2009). Aqueous extraction of virgin olive oil using industrial enzymes. Food Research International, 42(1), 171-175. http://dx.doi. org/10.1016/j.foodres.2008.10.002.

Nasri, N., Khaldi, A., Fady, B., \& Triki, S. (2005). Fatty acids from seeds of Pinus pinea L.: composition and population profiling. Phytochemistry, 66(14), 1729 -1735. PMid:16002105.

Nehdi, I. (2011). Characteristics, chemical composition and utilisation of Albizia julibrissin seed oil. Industrial Crops and Products, 33(1), 30-34. http://dx.doi.org/10.1016/j.indcrop.2010.08.004.

Oomah, B. D., Busson, M., Godfrey, D. V., \& Drover, J. C. G. (2002). Characteristics of hemp (Cannabis sativa L.) seed oil. Food Chemistry, 76(1), 33-43. http://dx.doi.org/10.1016/S0308-8146(01)00245-X.

Ranalli, A., Malfatti, A., Lucera, L., Contento, S., \& Sotiriou, E. (2005). Effects of the processing techniques on the natural colourings and the other functional constituents in virgin olive oil. Food Research International, 38(8-9), 873-878. http://dx.doi.org/10.1016/j. foodres.2005.02.011.

Tang, W., Sun, B. S., \& Zhao, Y. Q. (2014). Preparative separation and purification of rosmarinic acid from perilla seed meal via combined column chromatography. Journal of Chromatography B: Analytical Technologies in the Biomedical and Life Sciences, 947-948, 41-48. PMid:24381020. http://dx.doi.org/10.1016/j.jchromb.2013.12.007.

Tuberoso, C., Kowalczyk, A., Sarritzu, E., \& Cabras, P. (2007). Determination of antioxidant compounds and antioxidant activity in commercial oilseeds for food use. Food Chemistry, 103(4), 1494-1501. http:// dx.doi.org/10.1016/j.foodchem.2006.08.014.

Vuong, Q. V., Nguyen, V. T., Thanh, D. T., Bhuyan, D. J., Goldsmith, C. D., Sadeqzadeh, E., Scarlett, C. J., \& Bowyer, M. C. (2014). Optimization of ultrasound-assisted extraction conditions for euphol from the medicinal plant, Euphorbia tirucalli, using response surface methodology. Industrial Crops and Products, 63, 197-202. http://dx.doi.org/10.1016/j.indcrop.2014.09.057.

Wong, M., Timms, R., \& Goh, E. (1988). Colorimetric determination of total tocopherols in palmoil, olein and stearin. Journal of the American Oil Chemists' Society, 65(2), 258-261. http://dx.doi. org/10.1007/BF02636412.

Xu, Q., Shen, Y. Y., Wang, H. F., Zhang, N. P., Xu, S. H., \& Zhang, L. (2013). Application of response surface methodology to optimize extraction of flavonoids from fructus sophorae. Food Chemistry, 138(4), 2122-2129. PMid:23497866. http://dx.doi.org/10.1016/j. foodchem.2012.11.099.

Zhang, S., Zu, Y. G., Fu, Y. J., Luo, M., Liu, W., Li, J., \& Efferth, T. (2010). Supercritical carbon dioxide extraction of seed oil from yellow horn (Xanthoceras sorbifolia Bunge.) and its anti-oxidant activity. Bioresource Technology, 101(7), 2537-2544. PMid:20022744. http:// dx.doi.org/10.1016/j.biortech.2009.11.082.

Zhou, X. J., Yan, L. L., Yin, P. P., Shi, L. L., Zhang, J. H., Liu, Y. J., \& Ma, C. (2014). Structural characterisation and antioxidant activity evaluation of phenolic compounds from cold-pressed Perilla frutescens var. arguta seed flour. Food Chemistry, 164, 150-157. PMid:24996318. http://dx.doi.org/10.1016/j.foodchem.2014.05.062. 